\title{
Pressure ulcer prevention - more than a problem of documentation? An Evidence-based approach
}

\author{
Luise Heinrich ${ }^{1}$, Jochen Schmitt ${ }^{1}$, Maria Eberlein-Gonska ${ }^{2}$, Thomas Petzold ${ }^{1,2^{*}}$ \\ From Safety in hospitals: from strategy to implementation Annual Scientific Meeting 2015 \\ Graz, Austria. 29-30 September 2015
}

\section{Background}

The prevention of pressure ulcers (PU) is an important public health issue. At the University Hospital Carl Gustav Carus Dresden (UKD) the documentation of PU prevention is standardized. The Braden scale is used to detect PU risk [1-3]. After an initial evaluation of PU data from 2007 to 2011 of the UKD, the medical board decided to reduce the PU documentation in medical departments with PU incidence rate less than $0.5 \%[4,5]$. This was the first scientifically approach to evaluate the value of quality activities like PU documentation within the UKD. The aim of this study is to evaluate this modification of PU documentation.

\section{Materials and methods}

We conduct a prospective cohort study. Data sources provide the PU documentation and data from the Activities of Daily Living. Data from the medical departments of the UKD with PU incidence rate less than $0.5 \%(\mathrm{n}=12)$ were analyzed over a one year period (06/2013-05/2014). To detect differences in the PU incidence rate, the medical departments were asked to document every inpatient at admission, at change of patient's health condition and at discharge for one month ("General documentation"). About the period of eleven months, the documentation was done with PU risk or existing PU ("Individual documentation"). The documentation was performed by trained staff. The study was registered in the database health services research in Germany (VfD_12_003465).

\section{Results}

11 of 12 medical departments implement the recommendation of individual documentation. 23,192 patients could be included in the study. For 11,548 inpatients, no

\footnotetext{
* Correspondence: Thomas.Petzold@uniklinikum-dresden.de

'Center for Evidence-based Healthcare, University Hospital Carl Gustav Carus Dresden, Dresden, Germany

Full list of author information is available at the end of the article
}

initial assessment regarding the PU risk exists. The prevalence of PU amounts to $2 \%(\mathrm{n}=106)$. A total of 14 inpatients developed an incident PU during inpatient stay. The incidence rate with "general documentation" was $0.06 \%(\mathrm{n}=13)$ and with "individual documentation" $0.05 \%(\mathrm{n}=1)$. During hospitalization 77 inpatients improved and had a lower grade at discharge compared with admission. The time for the PU documentation decreased from annually 25,000 minutes in 2011 to 4,500 minutes in this study.

\section{Conclusions}

Between "general" and "individual documentation" of PU, the observed incidence rates hardly differ and are not higher than in the initial evaluation (2007-2011). The unknown initial PU risk is a limitation of this study. This lack of assessment is important to gather in the future routine care to derive care measures and to obtain meaningful data. The evidence-based approach of PU documentation represents a pragmatic and necessary way to enclose measures of quality management on relevant outcomes and ensure valuable medical care.

\section{Competing interests}

No external funding.

\section{Authors' details \\ 'Center for Evidence-based Healthcare, University Hospital Carl Gustav Carus Dresden, Dresden, Germany. ${ }^{2}$ Department for Quality and Medical Risk Management, University Hospital Carl Gustav Carus Dresden, Dresden, Germany.}

Published: 30 October 2015

\section{References}

1. Bergstrom N, Braden BJ, Laguzza A, Holman V: The Braden Scale for Predicting Pressure Sore Risk. Nurs Res 1987, 36(4):205-210.

2. Braden BJ, Bergstrom N: Clinical utility of the Braden scale for Predicting Pressure Sore Risk. Decubitus 1989, 2(3):44-46-50-51. 
3. Bergstrom N, Braden B, Kemp M, Champagne M, Ruby E: Predicting pressure ulcer risk: a multisite study of the predictive validity of the Braden Scale. Nurs Res 1998, 47(5):261-269.

4. Eberlein-Gonska M, Petzold T, Helass G, Albrecht DM, Schmitt J: The incidence and determinants of decubitus ulcers in hospital care: an analysis of routine quality management data at a university hospital. Dtsch Arztebl Int 2013, 110(33-34):550-556.

5. Petzold T, Eberlein-Gonska M, Schmitt J: Which factors predict incident pressure ulcers in hospitalized patients? A prospective cohort study. $\mathrm{Br}$ J Dermatol 2014, 170(6):1285-1290.

doi:10.1186/2056-5917-1-S1-A22

Cite this article as: Heinrich et al:: Pressure ulcer prevention - more than a problem of documentation? An Evidence-based approach. Safety in Health 2015 1(Suppl 1):A22

\section{Submit your next manuscript to BioMed Central} and take full advantage of:

- Convenient online submission

- Thorough peer review

- No space constraints or color figure charges

- Immediate publication on acceptance

- Inclusion in PubMed, CAS, Scopus and Google Scholar

- Research which is freely available for redistribution

Submit your manuscript at www.biomedcentral.com/submit 